\title{
ADVANCING NITROGEN FERTILIZATION OF CORN USING Brachiaria ruziziensis AS COVER CROP ${ }^{1}$
}

\author{
THIAGO PINHEIRO DE OLIVEIRA ${ }^{2}$, MAGNO GONSALVES BRAZ $^{2}$, ALEX OLIVEIRA SMANIOTTO $^{3}$, DANIELLE \\ FABÍOLA PEREIRA DA SILVA², SIMÉRIO CARLOS SILVA CRUZ ${ }^{2}$
}

\begin{abstract}
Advancing nitrogen (N) application in cropping systems, using cover crops, is an alternative to improve the efficiency of use of this nutrient and to optimize the operational issue. The aim of this study was to evaluate the efficiency of advancing $\mathrm{N}$ fertilization for corn crop, with Brachiaria ruziziensis as cover crop. The experiment was conducted at the experimental field of the Federal University of Jataí / Regional Unit of Jataí, GO, Brazil, with history of soybean-corn/sorghum succession in the last 20 years and a high organic matter content in the soil, which reaches $39.5 \mathrm{~g} \mathrm{~kg}^{-1}$. A randomized complete block design was used in a $5 \times 2+$ 1 factorial scheme with 4 replicates, corresponding to five $\mathrm{N}$ doses: $0 ; 50 ; 100 ; 150$ and $200 \mathrm{~kg} \mathrm{ha}^{-1}$ and two times of application in B. ruziziensis: Time 1 - $\mathrm{N}$ application 90 days before planting of corn, and Time $2-\mathrm{N}$ application 60 days before planting, plus an additional treatment with conventional $\mathrm{N}$ fertilization, $150 \mathrm{~kg} \mathrm{ha}{ }^{-1}$ of $\mathrm{N}$, not advanced, applied to the corn crop, split into planting fertilization and top-dressing fertilization. Except for the $\mathrm{N}$ dose of $200 \mathrm{~kg} \mathrm{ha}^{-1}$ applied 90 days before corn sowing, advancing $\mathrm{N}$ fertilization for this crop using $B$. ruziziensis as cover plant proved to be as efficient as conventional fertilization for the soil and climate conditions under which the study was carried out, that is, soil with high content of organic matter, built fertility and absence of water restriction.
\end{abstract}

Keywords: Zea mays L.. N availability. Nitrogen fertilization. Brachiaria ruziziensis.

\section{ANTECIPAÇÃO DO NITROGÊNIO PARA O MILHO EM FUNÇÃO DO USO DE BRAQUIÁRIA COMO PLANTA DE COBERTURA}

RESUMO - A antecipação da aplicação de nitrogênio em sistemas de cultivo, usando plantas de cobertura, apresenta-se como alternativa para melhorar a eficiência do uso desse nutriente e otimizar a questão operacional. Objetivou-se com este trabalho, avaliar a eficiência da antecipação da adubação nitrogenada para a cultura do milho, tendo a braquiária como cultura de cobertura. $\mathrm{O}$ experimento foi conduzido na área experimental da Universidade Federal de Jataí, em Jataí - GO, com histórico de plantio em sucessão sojamilho/sorgo nos últimos 20 anos, e destaque para o teor de matéria orgânica do solo que é de $39,5 \mathrm{~g} \mathrm{~kg}^{-1}$. Utilizou-se delineamento de blocos ao acaso, com fatorial $5 \times 2+1$, com 4 repetições, sendo cinco doses de N: 0; 50; $100 ; 150$ e $200 \mathrm{~kg} \mathrm{ha}^{-1}$ e duas épocas de aplicação na cultura da braquiária, sendo a época 1: aplicação do nitrogênio 90 dias pré-semeadura do milho e época 2: aplicação do nitrogênio 60 dias pré-semeadura do milho e um tratamento adicional com adubação nitrogenada convencional de $150 \mathrm{~kg} \mathrm{ha}^{-1}$ de nitrogênio, aplicada na cultura do milho, dividida em adubação de plantio e cobertura. Com exceção a dose de $200 \mathrm{~kg} \mathrm{ha}^{-1} \mathrm{de} \mathrm{N}$ aplicada 90 dias antes da semeadura do milho, a antecipação da adubação nitrogenada para esta cultura, utilizando a braquiária como planta de cobertura, se mostrou tão eficiente quando a adubação convencional nas condições de solo e clima em que foi realizado o trabalho, ou seja, solo com alto teor de matéria orgânica, fertilidade construída e ausência de restrição hídrica.

Palavras-chave: Zea mays L.. Disponibilidade de N. Adubação nitrogenada. Brachiaria ruziziensis.

\footnotetext{
${ }^{*}$ Corresponding author

${ }^{1}$ Received for publication in 05/20/2020; accepted in 09/21/2020.

Paper extracted from the master's dissertation of the first author.

${ }^{2}$ Academic Unit of Agricultural Sciences, Universidade Federal de Jataí, Jataí, GO, Brazil; thiagopinheiroagro@gmail.com - ORCID: 0000 -0002-4751-4426, magno.braz@discente.ufg.br - ORCID: 0000-0001-8470-0415, daniellefpsilva@ufg.br - ORCID: 0000-0001-7366-5650, simerio_cruz@yahoo.com.br - ORCID: 0000-0002-6327-8590.

${ }^{3}$ Postgraduate Programme in Agrarian Sciences, Instituto Federal Goiano, Rio Verde, GO, Brazil; aosmaniotto@gmail.com - ORCID: 0000 $-0001-8745-8935$
} 


\section{INTRODUCTION}

Corn (Zea mays L.) is one of the main cereals produced over the last few years, due to its importance to meet the demand of the human and animal food chain, whose consumption has gradually increased year after year. This increase can be explained due to its chemical composition and nutritional value, in addition to the high production potential of this crop (RODRIGUES et al., 2018). In the 2019/2020 season, Brazil harvested 102.1 million tons of corn, an increase of $2.1 \%$ compared to the previous harvest. Corn consumption for the 2019/20 season is estimated to be 68.4 million tons, driven by corn ethanol and the increase in meat exports (CONAB, 2020).

According to Prado and Campos (2018), the nutrient that most limits yield in corn crop is nitrogen $(\mathrm{N})$. These authors add that the amount required by the crop is not met by the process of mineralization of soil organic matter.

Atmospheric depositions, biological fixation, in addition to mineral and organic fertilization are the main ways for $\mathrm{N}$ to enter into the system. On the other hand, losses by leaching, volatilization and removal by harvesting are the main forms of $\mathrm{N}$ removal from the system. In order to increase $\mathrm{N}$ fertilization efficiency in corn crop, it is split into sowing fertilization and top-dressing fertilization (CANTARELLA, 2007).

Despite all the care taken in the management of $\mathrm{N}$ application in the system, it is known that the utilization by plants is still low. Thus, the inclusion of cover crops in the cropping system can contribute to increasing the efficiency of utilization of this nutrient, as reported by Crusciol and Soratto (2014). In addition, the presence of cover crops in the cropping systems increases the sustainability of the sector, since they contribute to the improvement of the physical, chemical and biological characteristics of the soil.

It should be considered that the time of application of $\mathrm{N}$ fertilizer will have great influence on the efficiency of its use by plants (MENGEL; BARBER, 1974) and this factor, combined with the dose and method of application, will also influence crop yield (HOEFT, 2003). Nitrogen fertilizer applied adequately and taking into account the cover crop reduces leaching losses in rainy years and volatilization in dry years (MA et al., 2010). This association improves the utilization of fertilizer-N when combined with the release of the residual-N contained in the vegetation cover (NUNES et al., 2011), reducing demand and losses (PINNOW et al., 2013).

In view of this, it is hypothesized that the advancing of $\mathrm{N}$ fertilization of corn, carried out in the cover plant, will increase its efficiency and promote benefits for the operationalization of this practice.

The objective of this study was to evaluate the efficiency of advancing $\mathrm{N}$ fertilization for corn using Brachiaria ruziziensis as previous crop.

\section{MATERIAL AND METHODS}

The present study was carried out in an experimental area of the Federal University of Jataí, in Jataí - GO, Brazil, located at $17^{\circ} 66^{\prime} \mathrm{S}$ and $51^{\circ} 33^{\prime}$ $\mathrm{W}$, with an average altitude of 700 meters. According to Köppen's climate classification, the predominant climate of the region is Aw - tropical, with high temperatures and high rainfall in summer and mild temperatures and low rainfall in winter.

The area used for the experiment has a history of soybean-corn/sorghum succession in the last 20 years, with soybean sown from October and corn/ sorghum in the second season, sown from the second half of January. The soil was classified as Latossolo Vermelho distroférrico (LVdf) (Oxisol) of clayey texture (665 $\mathrm{g} \mathrm{dm}^{-3}$ of clay). Prior to the installation of the experiment, soil samples were collected for physical and chemical characterization in the $0-20$ $\mathrm{cm}$ layer (Table 1). Attention should be paid to the high contents of organic matter and phosphorus in this soil, which also has an adequate classification for CEC, $\mathrm{pH}$, base saturation and calcium and magnesium contents (SOUSA; LOBATO, 2004), for being a soil with fertility built over time.

Table 1. Chemical and particle-size characterization, in the $0-20 \mathrm{~cm}$ layer, of the soil of the experimental area before the installation of the experiment.

\begin{tabular}{|c|c|c|c|c|c|c|c|c|c|}
\hline $\mathrm{pH}\left(\mathrm{CaCl}_{2}\right)$ & $\begin{array}{c}\mathrm{OM} \\
\mathrm{g} \mathrm{kg}^{-1}\end{array}$ & $\begin{array}{l}\text { P (mel.) } \\
\mathrm{mg} \mathrm{dm}^{-3}\end{array}$ & \multicolumn{6}{|c|}{ - } & $\mathrm{V} \%$ \\
\hline 5.10 & 39.50 & 8.80 & 0.22 & 3.87 & 1.98 & 0.08 & 4.30 & 10.40 & 58.40 \\
\hline $\mathrm{Fe}$ & $\mathrm{Mn}$ & $\mathrm{Zn}$ & $\mathrm{Cu}$ & $\mathrm{Na}$ & \multicolumn{2}{|c|}{ Clay } & Sand & \multicolumn{2}{|c|}{ Silt } \\
\hline & --- & $\mathrm{g} \mathrm{dm}^{-3}$ & --- & & \multicolumn{5}{|c|}{------------g kg-1 ----------- } \\
\hline 25.20 & 39.40 & 2.60 & 6.80 & 1.80 & \multicolumn{2}{|c|}{665} & 185 & \multicolumn{2}{|c|}{150} \\
\hline
\end{tabular}


The design used was randomized blocks, in a $5 \times 2+1$ factorial scheme, and 4 replicates. The first factor corresponded to five $\mathrm{N}$ doses: $0,50,100,150$ and $200 \mathrm{~kg} \mathrm{ha}^{-1}$, while the second corresponded to the times of application of $\mathrm{N}$ doses in Brachiaria ruziziensis cultivated as a cover plant: Time 1 - N application at 90 days prior to sowing (DPS) and Time 2 - N application at 60 DPS of corn crop, with an additional treatment of conventional $\mathrm{N}$ fertilization, represented by $150 \mathrm{~kg} \mathrm{ha}^{-1}$ of $\mathrm{N}$, not advanced, applied in corn crop, split into sowing fertilization (30 kg ha-1 of $\mathrm{N}$ ) and top-dressing fertilization $\left(120 \mathrm{~kg} \mathrm{ha}^{-1}\right.$ of $\left.\mathrm{N}\right)$. Each plot was $7 \mathrm{~m}$ long and $2.25 \mathrm{~m}$ wide (5 corn rows), totaling 15.75 $\mathrm{m}^{2}$ for each experimental unit urea $(44 \% \mathrm{~N})$. Urea was used as a source of $\mathrm{N}$.

In 2018, after soybean harvest, Brachiaria ruziziensis was sown on March 22 of the same year, using $5 \mathrm{~kg} \mathrm{ha}^{-1}$ of seeds with $90 \%$ cultural value (CV). After sowing the B. ruziziensis on the soybean crop remains, a leveling harrow was used in the area to increase the contact of $B$. ruziziensis seeds with the soil.

Prior to the sowing of B. ruziziensis, the soil was corrected based on the results obtained in its chemical analysis, according to the recommendation of Sousa and Lobato (2004). $1.5 \mathrm{Mg} \mathrm{ha}^{-1}$ of dolomitic limestone (RNV of $90 \%$ ) was applied in the soil, without incorporation, to correct base saturation to $70 \%$ as a function of the demand of corn crop.

During the experiment, between the first $\mathrm{N}$ fertilization in $B$. ruziziensis until the harvest of corn crop, the accumulated rainfall was $1,261 \mathrm{~mm}$ according to the meteorological data of INMET, as shown in Figure 1. On 03/12/2019, there was a hailstorm in the experimental area, causing lodging and some physical damage to corn plants, but without compromising the continuation of the study, as the damage to the plants occurred in a similar way in all plots of each block.

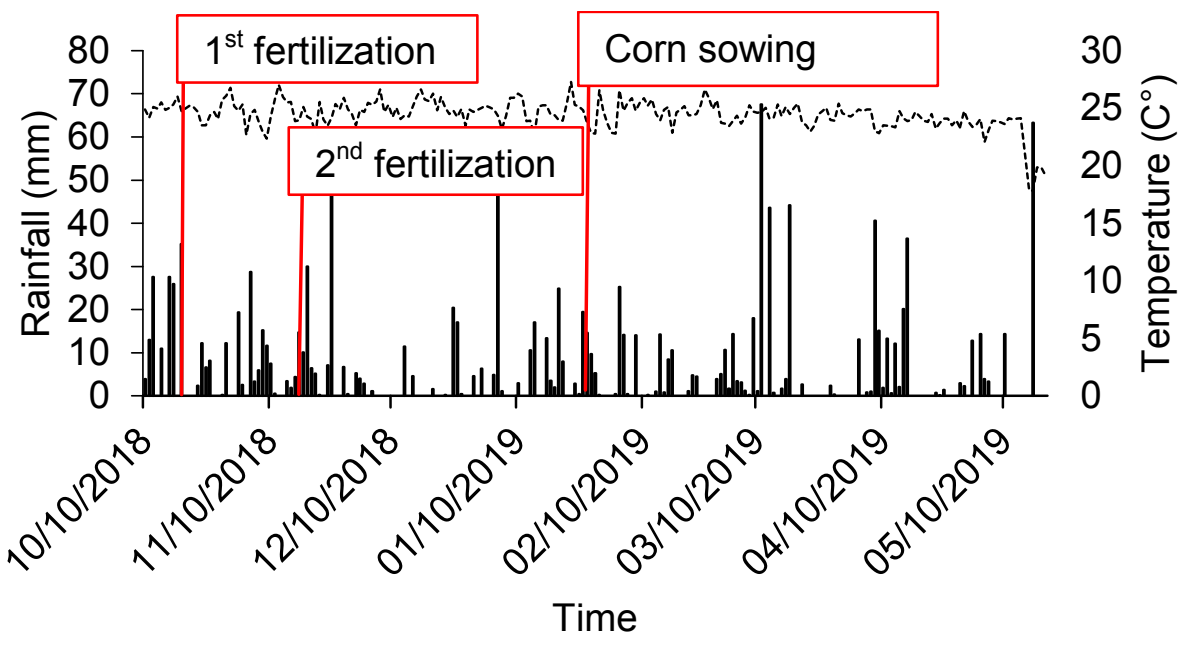

Rainfall (mm)

Average Temp. $\left({ }^{\circ} \mathrm{C}\right)$

Figure 1. Rainfall data during along the experiment.

The first time of $\mathrm{N}$ fertilization in $B$. ruziziensis, to characterize the variation factor related to the times, occurred on $10 / 14 / 2018$, with precipitation of $11 \mathrm{~mm}$ after application, while the second time of $\mathrm{N}$ fertilization occurred 30 days after the first one, on $11 / 13 / 2018$, with precipitation of 6 $\mathrm{mm}$ after application. B. ruziziensis desiccation for corn sowing was performed on 12/13/2018, which corresponds to 30 days after the second time of fertilization.

Corn sowing was carried out on $01 / 17 / 2019$, 35 days after desiccation of the cover crop, respecting a limit longer than 14 days after desiccation according to Corrêa et al. (2008), and the large volume of straw produced by $B$. ruziziensis delayed planting after the desiccation process. Sowing was performed using the hybrid RB 9110 $\mathrm{PRO}$, with spacing of $0.45 \mathrm{~m}$ between rows and an average of 3 seeds per meter. Fertilization at sowing consisted of $90 \mathrm{~kg} \mathrm{ha}^{-1}$ of $\mathrm{P}_{2} \mathrm{O}_{5}$ and $60 \mathrm{~kg} \mathrm{ha}^{-1}$ of $\mathrm{K}_{2} \mathrm{O}$, using single superphosphate and potassium chloride as sources, respectively. In the additional treatment, besides this fertilization with $\mathrm{P}_{2} \mathrm{O}_{5}$ and $\mathrm{K}_{2} \mathrm{O}, 30 \mathrm{~kg} \mathrm{ha}^{-1}$ of $\mathrm{N}$ were added, with $120 \mathrm{~kg} \mathrm{ha}^{-1}$ of $\mathrm{N}$ as top-dressing, when the plants were at stage V4.

In $B$. ruziziensis (cover plant), dry mass $\left(\mathrm{kg} \mathrm{ha}{ }^{-1}\right)$ was evaluated 90 days after the first fertilization. Subsequently, these samples were ground and sent to the laboratory for determination of $\mathrm{N}$ content. 
In the corn crop, the following variables were evaluated: activity of nitrate reductase enzyme at phenological stage V6, using the 3rd fully developed leaf, collected at approximately 9 a.m., on a sunny day, subjected to laboratory analysis following the methodology proposed by Meguro and Magalhães (1982); stem diameter at the second internode height from the soil; and chlorophyll index at the phenological stage VT, with the chlorophyll meter clorofiLOG CFL 1030 - Falker company, using the 10th fully developed leaf, performing the readings at two points of the middle third of each leaf, always around 10 a.m.; and $\mathrm{N}$ content in the leaf below and opposite to the ear, collected at the phenological stage R1. All evaluations were standardized with 10 repetitions per experimental unit. The production component 1000 grain weight $(1000 \mathrm{GW})$ was also evaluated. For grain yield, because of the lodging, it was decided to collect only the ears present in the central $3.5 \mathrm{~m}$ of the middle row of each experimental unit, which were mechanically threshed to determine the grain mass per experimental unit, which was extrapolated to $\mathrm{kg} \mathrm{ha}^{-1}$.

Statistical analysis of the data was performed using the statistical program Assistat (SILVA;
AZEVEDO, 2009). The obtained data were subjected to analysis of variance by $\mathrm{F}$ test at 1 and $5 \%$ probability levels. For the variable "nitrate reductase activity", the obtained data were subjected to analysis of variance by $\mathrm{F}$ test at $10 \%$ probability level, following guidelines found in the literature due to the variation in the incidence of solar radiation in plants at the time of collection, promoting a microclimate that alters enzymatic activity (LEMOS et al., 2007). Data on the "N dose variation" factor were subjected to regression analysis. The additional treatment was also compared with the other treatments by the Dunnett Test, using the statistical program RBIO.

\section{RESULTS AND DISCUSSION}

For the variables shoot dry mass (SDM) and $\mathrm{N}$ content in the SDM of B. ruziziensis, there was interaction between the sources of variation application times and $\mathrm{N}$ doses. For the $\mathrm{N}$ content in the SDM of B. ruziziensis, there was no significant effect of the treatments (Table 2).

Table 2. Summary of the analysis variance $(\operatorname{Pr}(>\mathrm{Fc}))$ for: block, times of application $/ \mathrm{N}$ doses and their interactions for shoot dry mass and nitrogen content in dry mass.

\begin{tabular}{lcc}
\hline \multirow{2}{*}{ Source of variation } & \multicolumn{2}{c}{$\operatorname{Pr}(>\mathrm{Fc})$} \\
\cline { 2 - 3 } & Dry mass & $\mathrm{N}$ in dry mass \\
\hline Block & 0.444 & 0.001 \\
Application times (A) & 0.030 & 0.392 \\
N doses (B) & 0.017 & 0.386 \\
Interaction A*B & 0.001 & 0.935 \\
\hline CV & 15.33 & 14.16 \\
\hline Linear Regression & 0.220 & 0.051 \\
\hline Quadratic Regression & 0.695 & 0.807 \\
\hline
\end{tabular}

Significant at $1 \%$ probability level $(\mathrm{p}<0.01)$. Significant at $5 \%$ probability level $(0.01=<\mathrm{p}<0.05)$.

When evaluating the decomposition of the interaction between application times and $\mathrm{N}$ doses for SDM of B. ruziziensis, significant effect was only observed at the dose of $100 \mathrm{~kg} \mathrm{ha}^{-1}$, for which Time 2 caused a greater increase in dry mass production (Table 3). There was no fit of linear or quadratic equation for the $\mathrm{N}$ doses used in B. ruziziensis in any fertilization time.

Gomes et al. (2015) remind that the success of $\mathrm{N}$ fertilization in forage crops for dry mass production is associated with several factors, such as soil organic matter content and water availability. It should be noted that in the present study the soil had a high organic matter content, and no water restriction period was detected.

The non-significant effect on $\mathrm{N}$ content in the SDM of B. ruziziensis as a function of treatments can be explained by the high organic matter content in the soil and also by the appropriate climatic condition during the $B$. ruziziensis evaluation period. It was found that all treatments had adequate $\mathrm{N}$ values for crops of the genus Brachiaria, between 13 and $20 \mathrm{~g} \mathrm{~kg}^{-1}$ (OLIVEIRA et al., 2007), highlighting the importance of studying the nutritional status of the forage crop. 
Table 3. Decomposition of the interaction between application times and $\mathrm{N}$ doses applied in the B. ruziziensis, for the variable shoot dry mass $\left(\mathrm{kg} \mathrm{ha}^{-1}\right)$.

\begin{tabular}{cccccc}
\hline & \multicolumn{5}{c}{$\mathrm{N}$ doses $\left(\mathrm{kg} \mathrm{ha}^{-1}\right)$} \\
\cline { 2 - 6 } Treatments & 0 & 50 & 100 & 150 & 200 \\
\hline Time 1 & 2117.31 & 1724.52 & 1989.81 & 2412.93 \\
Time 2 & 2125.53 & 1933.68 & 3179.95 & 1902.65 & 2388.09 \\
\hline p-value & --- & 0.446 & 0.001 & 0.716 & 0.917 \\
\hline
\end{tabular}

Regarding the results of the corn crop evaluations, there was significant interaction for stem diameter as a function of $\mathrm{N}$ doses and application times in B. ruziziensis.

When analyzing the simple effect of application times (Table 4) at each $\mathrm{N}$ dose, a significant effect was detected only at the $\mathrm{N}$ dose of $200 \mathrm{~kg} \mathrm{ha}^{-1}$, for which the fertilization applied at 60 days prior to sowing of corn (Time 2) promoted a greater increase in stem diameter compared to the application at 90 days prior to sowing of corn (Time 1).

Table 4. Decomposition of the interaction between application times and $\mathrm{N}$ doses applied in B. ruziziensis, on the stem diameter $(\mathrm{mm})$ of corn cultivated in succession to B. ruziziensis.

\begin{tabular}{cccccc}
\hline \multirow{2}{*}{ Treatments } & \multicolumn{5}{c}{$\mathrm{N}$ doses $\left(\mathrm{kg} \mathrm{ha}^{-1}\right)$} \\
\cline { 2 - 6 } & 0 & 50 & 100 & 150 & 200 \\
\hline Time 1 & \multirow{2}{*}{21.65} & 22.17 & 21.70 & 22.38 & 20.72 \\
Time 2 & & 21.80 & 22.35 & 23.06 & 23.10 \\
\hline p-value & --- & 0.463 & 0.202 & 0.183 & 0.001 \\
\hline
\end{tabular}

Significant at $1 \%$ probability level $(\mathrm{p}<0.01)$ by F test. Significant at $5 \%$ probability level $(0.01=<\mathrm{p}<0.05)$ by $\mathrm{F}$ test. Not significant $(\mathrm{p}>=0.05)$.

By analyzing the simple effect of $\mathrm{N}$ doses at each application time, it is possible to note that, for Time 1, the means of stem diameter were described by a quadratic regression equation, with the highest value found at the $\mathrm{N}$ dose of $82.06 \mathrm{~kg} \mathrm{ha}^{-1}$. It was verified that, in Time 2, a positive linear regression equation was fitted (Figure 2).

According to Soratto et al. (2010), this difference is morphologically important because the larger stem diameter is directly related to the reduction in the risk of lodging. According to Kappes et al. (2011), the increase in stem diameter for corn crop is relevant, since the larger the stem diameter, proportionally, the greater the accumulation of reserves and, consequently, production. This has also been observed by Cruz et al. (2008), who found a positive correlation between stem diameter and grain yield for three hybrids and a variety of corn, in a study involving the management of $\mathrm{N}$ fertilization for this crop. This relationship between stem diameter and yield was also observed in the present study, since the treatment with $200 \mathrm{~kg}$ $\mathrm{ha}^{-1}$ of $\mathrm{N}$ in Time 2 also led to the highest grain yield.

By evaluating the physiological parameters of corn crop, it was possible to observe that there was interaction between the sources of variation application times and $\mathrm{N}$ doses only for nitrate reductase activity. Considering the sources of variation separately, a significant effect was observed only for $\mathrm{N}$ doses on chlorophyll index.

In the decomposition of the interaction between fertilization times and $\mathrm{N}$ doses for nitrate reductase activity (Table 5), it is possible to note that, for the $\mathrm{N}$ doses of 100,150 and $200 \mathrm{~kg} \mathrm{ha}^{-1}$, the first time of fertilization promoted higher enzyme activity when compared to the second time.

It is understood that enzymatic activity is a complementary tool for understanding the nutrition of plants as it is active in the inorganic $\mathrm{N}$ assimilation pathway. Its values can be altered and controlled by a series of environmental stimuli and stimuli that are intrinsic to the plant (MAZID; KHAN; MOHAMMAD, 2012). Campbell (1999) reminds that the genetic material and oscillating environmental factors during the day, mainly as a function of light, interfere in enzyme activity, with lower activity in periods of the day with low luminosity, as reported by Scheible, Gonzáles-Fontes and Lauerer (1997). 


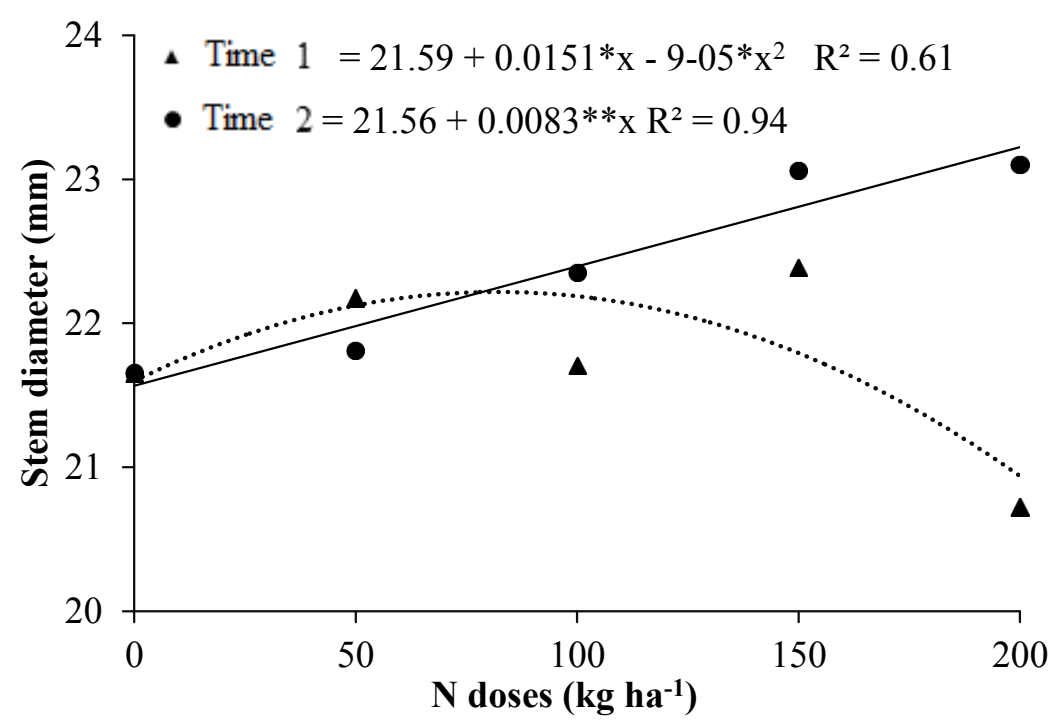

Figure 2. Corn stem diameter as a function of the time of advance in nitrogen fertilization, applied in B. ruziziensis and $\mathrm{N}$ doses. $*$ and $* *$ Significant at 5 and $1 \%$ probability levels by $\mathrm{F}$ test.

Table 5. Decomposition of the interaction between application times and $\mathrm{N}$ doses applied in the $B$. ruziziensis, for nitrate reductase activity $\left(\mathrm{NO}_{2}-\mathrm{H}^{-1} \mathrm{~g}^{-1} \mathrm{FM}\right)$ of corn cultivated in succession.

\begin{tabular}{cccccc}
\hline & \multicolumn{5}{c}{$\mathrm{N}$ doses $\left(\mathrm{kg} \mathrm{ha}^{-1}\right)$} \\
\cline { 2 - 6 } Treatments & 0 & 50 & 100 & 150 & 200 \\
\hline Time 1 & 3.89 & 4.72 & 6.94 & 9.18 & 7.22 \\
Time 2 & & 4.16 & 3.33 & 5.00 & 4.16 \\
\hline p-value & --- & 0.757 & 0.054 & 0.028 & 0.098 \\
\hline
\end{tabular}

Significant at $1 \%$ probability level $(\mathrm{p}<0.01)$ by F test. Significant at $5 \%$ probability level $(0.01=<\mathrm{p}<0.05)$ by $\mathrm{F}$ test. Significant at $10 \%$ probability level $(0.01=<\mathrm{p}<0.1)$ by $\mathrm{F}$ test. Not significant $(\mathrm{p}>=0.1)$.

For the chlorophyll index, the means were described by a positive linear regression equation, that is, the chlorophyll index was increased as the $\mathrm{N}$ doses increased (Figure 3) regardless of the time of $\mathrm{N}$ application in B. ruziziensis.

The values found corroborate the results reported by Argenta et al. (2003), who conducted a study with corn hybrids and $\mathrm{N}$ doses and observed positive linear regression for chlorophyll content in the crop at different phenological stages.

The $\mathrm{N}$ content in corn leaf, regardless of the dose or time of application, averaged $29.32 \mathrm{~g} \mathrm{~kg}^{-1}$ of dry mass, that is, an adequate level for the crop according to the recommended values, between 28 and $35 \mathrm{~g} \mathrm{~kg}^{-1}$ (SOUSA; LOBATO, 2004).

There was significant interaction between application times and $\mathrm{N}$ doses only for yield. When the sources of variation were analyzed separately, a significant effect of application times on 1000-grain weight was observed.

The 1000-grain weight was favored by the advance of $\mathrm{N}$ fertilization to close to corn sowing, Time 2 (Table 6).

Kappes et al. (2011) mention that larger stems tend to accumulate a greater amount of photosynthates that will be translocated to the grains later, thus increasing their weight. According to Taiz and Zeiger (2013), these factors contribute to the increase in 1000-grain weight due to the accumulation and assimilation of carbohydrates.

An analysis of the simple effect of application times at each $\mathrm{N}$ dose for grain yield showed that the application time 1 did not differ from Time 2 at the $\mathrm{N}$ doses of 50,100 and $150 \mathrm{~kg} \mathrm{ha}^{-1}$. However, it was found that Time 2 promoted a greater increase in grain yield compared to Time 1 at the $\mathrm{N}$ dose of $200 \mathrm{~kg} \mathrm{ha}^{-1}$ (Table 7).

This can be explained by the better utilization of the $\mathrm{N}$ applied in the cover crop on a date closer to the sowing of corn. Similar results were found by Momesso et al. (2019), who worked with the advance of $\mathrm{N}$ fertilization in corn crop ranging from 50 to 1 day prior to corn sowing, using the species Brachiaria brizantha and Brachiaria ruziziensis as cover crops, and concluded that the closer the $\mathrm{N}$ application is to corn sowing, the better the $\mathrm{N}$ utilization and grain yield. 


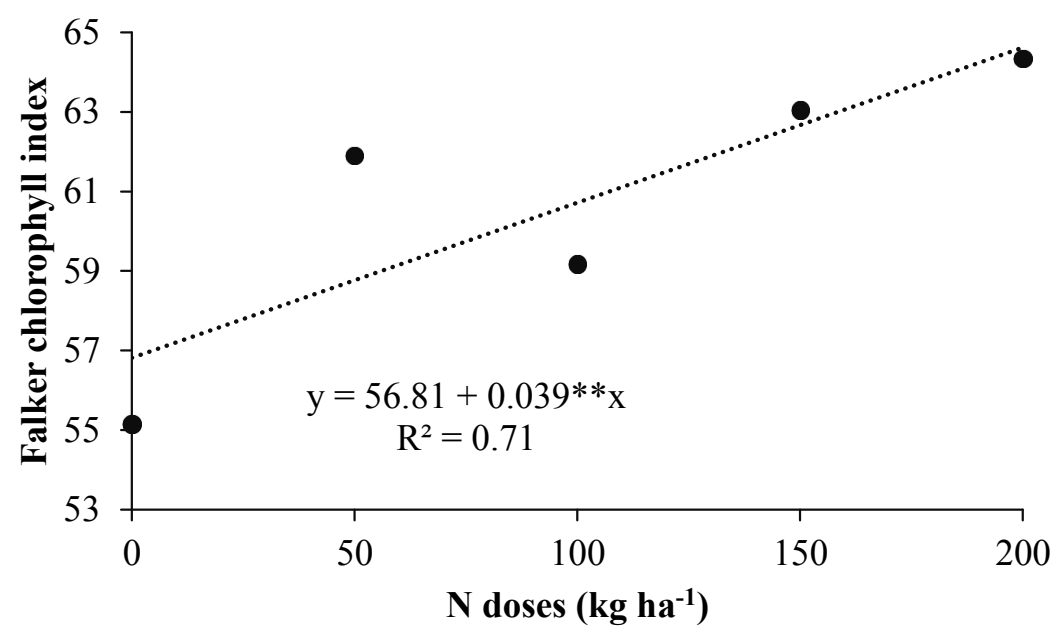

Figure 3. Chlorophyll index in corn leaves as a function of nitrogen doses applied in B. ruziziensis as cover crop cultivated prior to corn. **Significant at $1 \%$ probability level by $\mathrm{F}$ test.

Table 6. 1000-grain weight (g) of corn as a function of the times of $\mathrm{N}$ application in B. ruziziensis, regardless of the dose used.

\begin{tabular}{cc}
\hline Treatments & 1000-grain weight \\
\hline Time 1 & 275.77 \\
Time 2 & 283.97 \\
\hline p-value & 0.044 \\
\hline
\end{tabular}

Significant at $1 \%$ probability level $(\mathrm{p}<0.01)$ by $\mathrm{F}$ test. Significant at $5 \%$ probability level $(0.01=<\mathrm{p}<0.05)$ by F-Test. Not significant $(\mathrm{p}>=0.05)$.

Table 7. Decomposition of the interaction between application times and $\mathrm{N}$ doses applied in B. ruziziensis, on corn yield $\left(\mathrm{kg} \mathrm{ha}^{-1}\right)$.

\begin{tabular}{cccccc}
\hline \multirow{2}{*}{ Treatments } & \multicolumn{5}{c}{$\mathrm{N} \mathrm{doses( \textrm {kg } \mathrm { ha } ^ { - 1 } )}$} \\
\cline { 2 - 5 } & 0 & 50 & 100 & 150 & 200 \\
\hline Time 1 & \multirow{2}{*}{$6,641.14$} & $7,210.22$ & $7,637.31$ & $7,315.35$ & $6,460.49$ \\
Time 2 & & $7,810.41$ & $7,764.22$ & $7,868.12$ & $8,666.94$ \\
\hline p-value & --- & 0.166 & 0.766 & 0.201 & 0.001 \\
\hline
\end{tabular}

Significant at $1 \%$ probability level $(\mathrm{p}<0.01)$ by $\mathrm{F}$ test. Significant at $5 \%$ probability level $(0.01=<\mathrm{p}<0.05)$ by $\mathrm{F}$ test. Not significant $(\mathrm{p}>=0.05)$.

In the analysis of the simple effect of $\mathrm{N}$ doses at each application time (Figure 4), it was observed that in Time 2 a positive linear regression equation was fitted, that is, with the increase in $\mathrm{N}$ doses, there was an increase in corn yield. For Time 1, it was noted that the means were described by a quadratic regression equation, where the maximum agronomic efficiency was obtained at the $\mathrm{N}$ dose of

\section{$97.47 \mathrm{~kg} \mathrm{ha}^{-1}$.}

The results obtained for yield are directly related to the values found for stem diameter, a morphological parameter, and to the values of 1000grain weight, a production parameter, which shows better utilization of $\mathrm{N}$ by the corn plant when it is applied closer to sowing. 


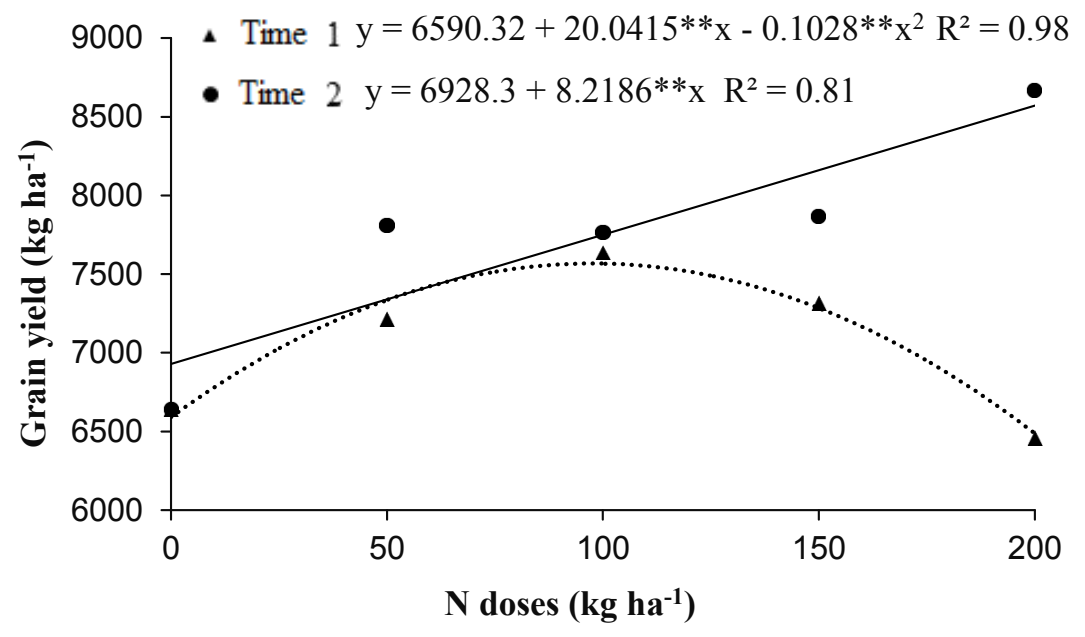

Figure 4. Decomposition of the interaction between application times and nitrogen doses applied in B. ruziziensis, on the grain yield of corn cultivated in succession. ${ }^{*}$ Significant at $1 \%$ probability level by $\mathrm{F}$ test.

It should be pointed out that the yields obtained in this study were low considering the potential of this crop in the region. However, this can be explained by the hailstorm that occurred during the crop cycle, which caused physical injuries to plants, as previously mentioned.
An analysis of the data with application of the Dunnett test for stem diameter showed that the association of the treatments Time 1 with the $\mathrm{N}$ dose of $200 \mathrm{~kg} \mathrm{ha}^{-1}$ resulted in a smaller stem diameter compared to the additional treatment (Table 8).

Table 8. Dunnett test for stem diameter (SD) in corn crop.

\begin{tabular}{cccc}
\hline & Treatment & SD \\
\hline Time & Dose $\left(\mathrm{kg} \mathrm{ha}^{-1}\right)$ & $\mathrm{mm}$ \\
\hline 1 & 200 & $20.72 \mathrm{~b}$ \\
$*$ & $*$ & $22.20 \mathrm{a}$ \\
\hline & Additional Treatment & $22.63 \mathrm{a}$ \\
\hline
\end{tabular}

Means followed by the letter (a) in the column do not differ from the additional treatment and those followed by (b) differ from the additional treatment, according to Dunnett test $(\mathrm{p}<0.05)$. *mean of all other 9 treatments that did not differ from the additional treatment.

Table 9 presents the results of Dunnett test for the variables nitrate reductase activity, chlorophyll index and $\mathrm{N}$ content in corn leaves.

The physiological variables evaluated are directly related to the nutritional status of the plant, and the non-significant results for some variables (nitrate reductase activity) can be explained by the high OM content in the soil, $39.5 \mathrm{~g} \mathrm{~kg}^{-1}$ (Table 1), since $\mathrm{N}$ availability in the soil is directly influenced by the amount of organic matter it has and by the materials that make up the plant residues present (AMADO et al., 2001; SIQUEIRA NETO, 2010). In addition, a high dry mass production of the forage crop was obtained in all treatments (Table 3), which had adequate $\mathrm{N}$ contents in the leaf tissue of $B$. ruziziensis, even in the control plants.

For the chlorophyll index, treatments with no $\mathrm{N}$ fertilization were inferior to the additional treatment, as frequently reported in the literature. According to Andrade et al. (2003), this is due to the role played by $\mathrm{N}$ in plant metabolism, because the biosynthesis of proteins and chlorophylls is directly linked to the availability of this nutrient. However, it is important to highlight that this soil has $39.5 \mathrm{~g} \mathrm{~kg}^{-1}$ of organic matter, which could have led to a different result, depending on the natural supply of $\mathrm{N}$.

It can be noted that the additional treatment promoted higher $\mathrm{N}$ content in corn leaves compared to treatments without $\mathrm{N}$ fertilization, Time $1 / 50 \mathrm{~kg}$ $\mathrm{ha}^{-1}$ of $\mathrm{N}$, Time $1 / 100 \mathrm{~kg} \mathrm{ha}^{-1}$ of $\mathrm{N}$ and Time $2 / 50$ $\mathrm{kg} \mathrm{ha}^{-1}$ of $\mathrm{N}$. It is also observed that the application of 150 and $200 \mathrm{~kg} \mathrm{ha}^{-1}$ of $\mathrm{N}$, regardless of the time of advance, promoted $\mathrm{N}$ contents in corn leaves statistically equal to those obtained in the additional treatment. 
Table 9. Dunnett test for nitrate reductase activity (NRED), Falker chlorophyll index (FCI) and N content in corn leaves.

\begin{tabular}{ccccc}
\hline & Treatment & NRED & FCI & N content \\
\hline Time & Dose $\left(\mathrm{kg} \mathrm{ha}^{-1}\right)$ & $\mathrm{NO}_{2-} \mathrm{H}^{-1} \mathrm{~g}^{-1} \mathrm{FM}$ & $\mathrm{g} \mathrm{kg}^{-1}$ \\
\hline 1 & 0 & $3.89 \mathrm{a}$ & $55.14 \mathrm{~b}$ & $27.65 \mathrm{~b}$ \\
1 & 50 & $4.72 \mathrm{a}$ & $60.11 \mathrm{a}$ & $28.17 \mathrm{~b}$ \\
1 & 100 & $6.94 \mathrm{a}$ & $60.05 \mathrm{a}$ & $28.35 \mathrm{~b}$ \\
1 & 150 & $9.18 \mathrm{a}$ & $59.75 \mathrm{a}$ & $29.22 \mathrm{a}$ \\
1 & 200 & $4.16 \mathrm{a}$ & $63.56 \mathrm{a}$ & $29.05 \mathrm{a}$ \\
2 & 0 & $3.89 \mathrm{a}$ & $55.14 \mathrm{~b}$ & $27.65 \mathrm{~b}$ \\
2 & 50 & $4.16 \mathrm{a}$ & $63.66 \mathrm{a}$ & $28.35 \mathrm{~b}$ \\
2 & 100 & $3.33 \mathrm{a}$ & $59.28 \mathrm{a}$ & $30.62 \mathrm{a}$ \\
2 & 150 & $5.00 \mathrm{a}$ & $66.33 \mathrm{a}$ & $29.40 \mathrm{a}$ \\
2 & 200 & $7.22 \mathrm{a}$ & $65.09 \mathrm{a}$ & $31.50 \mathrm{a}$ \\
\hline
\end{tabular}

Means followed by the letter (a) in the column do not differ from the additional treatment and those followed by (b) differ from the additional treatment, according to Dunnett test $(\mathrm{p}<0.05)$.

The results of Dunnett test, for the production parameters, showed that there was a significant effect on 1000-grain weight and grain yield of corn (Table 10). The additional treatment showed a higher 1000 -grain weight when compared to treatments without $\mathrm{N}$ fertilization, and for the $\mathrm{N}$ doses of 50 , 100 and $150 \mathrm{~kg} \mathrm{ha}^{-1}$ applied at 90 DPS. For this variable, it was noted that all $\mathrm{N}$ doses $(50,100,150$ and $200 \mathrm{~kg} \mathrm{ha}^{-1}$ ) applied at 60 DPS were statistically equal to the additional treatment. For the fertilization performed at 90 DPS, only the highest dose $\left(200 \mathrm{~kg} \mathrm{ha}^{-1}\right)$ was similar to the additional treatment, so, for this variable, the advance of $\mathrm{N}$ fertilization had the same efficiency when the maximum dose was applied at $90 \mathrm{DPS}$, or regardless of the $\mathrm{N}$ dose applied at 60 DPS.

Table 10. Dunnett test for 1000-grain weight (1000GW) and grain yield (GY) of corn.

\begin{tabular}{ccccc}
\hline & Treatment & & $1000 \mathrm{GW}$ & $\mathrm{GY}$ \\
\hline Time & $\begin{array}{c}\text { Dose } \\
\left(\mathrm{kg} \mathrm{ha}^{-1}\right)\end{array}$ & $\mathrm{g}$ & $\mathrm{kg} \mathrm{ha}^{-1}$ \\
\hline 1 & 0 & $274.21 \mathrm{~b}$ & $6641.13 \mathrm{~b}$ \\
1 & 50 & $261.24 \mathrm{~b}$ & $7210.22 \mathrm{a}$ \\
1 & 100 & $268.84 \mathrm{~b}$ & $7637.30 \mathrm{a}$ \\
1 & 150 & $265.66 \mathrm{~b}$ & $7315.34 \mathrm{a}$ \\
1 & 200 & $288.91 \mathrm{a}$ & $6460.48 \mathrm{~b}$ \\
2 & 0 & $274.21 \mathrm{~b}$ & $6641.13 \mathrm{~b}$ \\
2 & 50 & $282.95 \mathrm{a}$ & $7810.40 \mathrm{a}$ \\
2 & 100 & $292.79 \mathrm{a}$ & $7764.21 \mathrm{a}$ \\
2 & 150 & $285.77 \mathrm{a}$ & $7868.11 \mathrm{a}$ \\
\hline & 200 & $284.16 \mathrm{a}$ & $8666.94 \mathrm{a}$ \\
\hline
\end{tabular}

Means followed by the letter (a) in the column are equal to the additional treatment and those followed by (b) differ from the control, according to Dunnett test $(\mathrm{p}<0.05)$. 
For corn grain yield, the additional treatment promoted a greater increase ( 24 and $27 \%$ ) compared to treatments with no $\mathrm{N}$ fertilization and the Time $1 / 200 \mathrm{~kg} \mathrm{ha}^{-1} \mathrm{~N}$, respectively, and the latter treatment was responsible for the lowest value of corn grain yield per hectare, besides lead to lower stem diameter (Figure 2), which may be directly related to the accumulation of photoassimilates and consequently grain yield.

The absence of response of the corn crop to the advance in $\mathrm{N}$ fertilization, when compared to the additional treatment (conventional fertilization at planting and as top-dressing) may be related to both possible losses of $\mathrm{N}$ in the system and to the luxury accumulation by the plant, because it had adequate $\mathrm{N}$ contents in the leaf tissue and, as mentioned by Malavolta, Vitti and Oliveira (1989), the high absorption rate and subsequent accumulation of nutrients by the crops may not represent an increase in yield. In addition, the rainfall regime, soil organic matter content, cover crop, original $\mathrm{N}$ content in the soil and type of soil are factors that influence the absence of responses to $\mathrm{N}$ fertilization management (ARAÚJO et al., 2007).

\section{CONCLUSIONS}

Except for the $\mathrm{N}$ dose of $200 \mathrm{~kg} \mathrm{ha}^{-1}$ applied 90 days prior to corn sowing, the advance in $\mathrm{N}$ fertilization for this crop using $B$. ruziziensis as a cover plant was as efficient as conventional fertilization for the soil and climate conditions under which the study was carried out, that is, soil with high organic matter content, built fertility and absence of water restriction.

\section{REFERENCES}

ANDRADE, A. C. et al. Adubação nitrogenada e potássica em capim-elefante (Pennisetum purpureum Schum. cv. Napier). Ciência e Agrotecnologia, 27: 1643-1651, 2003.

ARAÚJO, C. et al. Critérios para a determinação da dose de nitrogênio a ser aplicada no tomateiro em ambiente protegido. Horticultura Brasileira, 25: 327-333, 2007.

ARGENTA, G. et al. Adubação nitrogenada em milho pelo monitoramento do nível de nitrogênio na planta por meio de clorofilômetro. Revista Brasileira de Ciência do Solo, 27: 109-119, 2003.

AMADO, T. J. C. et al. Potencial de culturas de cobertura em acumular carbono e nitrogênio no solo no plantio direto e a melhoria da qualidade ambiental. Revista Brasileira de Ciência do Solo,

\section{5: 189-197, 2001}

CAMPBELL, W. H. Nitrate reductase structure function and regulation on bridging to gap between biochemistry and physiology.Anual Revew Plant Physiology Plant Molecular Biology, 50: 277-303. 1999.

CANTARELLA, H. Nitrogênio. In: NOVAIS, R. F. et al. (Eds.). Fertilidade do solo. Viçosa, MG: Sociedade Brasileira de Ciência do Solo, 2007. v. 1, cap. 7 , p. $375-470$.

CONAB - Companhia Nacional de Abastecimento. Acompanhamento da safra brasileira de grãos. Disponível em: <www.conab.gov.br>. Acesso em: 22 ago. 2020.

CORRÊA, J. C. et al. Efeito do intervalo de dessecação antecedendo a semeadura do milho e do uso de diferentes espécies de plantas de cobertura. Revista Brasileira de Ciência do Solo, 32: 739-746, 2008.

CRUSCIOL, C. A. C.; SORATTO, R. P. Sistema de produção e eficiência agronômica de fertilizantes. In: PROCHNOW, L. I.; CASARIN, V.; STIPP, S. R. (Eds.). Boas práticas para uso eficiente de fertilizantes: Contexto mundial e técnicas de suporte. Piracicaba, SP: International Plant Nutrition Institute, 2014. v. 1, cap. 9, p. 229-275.

CRUZ, S. C. S. et al. Adubação nitrogenada para milho cultivado em sistema plantio direto, no Estado de Alagoas. Revista Brasileira de Engenharia Agrícola e Ambiental, 12: 62-68, 2008.

GOMES, E. P. et al. Produtividade de capim tifton 85 sob irrigação e doses de nitrogênio. Revista Brasileira de Engenharia Agrícola e Ambiental, 19: 317-323, 2015.

HOEFT, R. G. Desafios para a obtenção de altas produtividades de milho e de soja nos EUA. Piracicaba, SP: POTAFÓS, 2003. 20 p.

KAPPES, C. et al. Desempenho de híbridos de milho em diferentes arranjos espaciais de plantas. Bragantia, 70: 333-334, 2011.

LEMOS, C. L.et al. Os efeitos do sombreamento na atividade da redutase de nitrato em folhas de coffea arábica L. Revista Brasileira de Agroecologia, 2: 1070-1074,2007.

MA, B. L. et al. On-farm assessment of the amount and timing of nitrogen fertilizer on ammonia volatilization. Agronomy Journal, 102: 134-144, 2010 . 
MALAVOLTA, E.; VITTI, G. C.; OLIVEIRA, A. S. Avaliação do estado nutricional das plantas: princípios e aplicações. Piracicaba, SP: Associação Brasileira para Pesquisa da Potassa e do Fosfato, 1989. $201 \mathrm{p}$.

MAZID, M.; KHAN, T. A.; MOHAMMAD, F. Role of nitrate reductase in nitrogen fixation under photosynthetic regulation.World Jornal of Pharmaceutical Research, 1: 384-414, 2012.

MEGURO, N.E.; MAGALHÃES, A.C. Atividade da redutase de nitrato em cultivares de café. Pesquisa Agropecuária Brasileira, 17: 249-257, 1982.

MENGEL, D. B.; BARBER, S. A. Rate of nutrient uptake per unit of corn root under field conditions. Agronomy Journal, 66: 399-402, 1974.

MOMESSO, L. et al. Impacts of Nitrogen Management on No-Till Maize Production Following Forage Cover Crops. Agronomy Journal, 111: 639-649, 2019.

NUNES, A. S. et al. Adubos verdes e doses de nitrogênio em cobertura na cultura do trigo sob plantio direto. Semina: Ciências Agrárias, 32: 1375 $-1384,2011$.

OLIVEIRA, P. P. A. et al. Guia de identificação de deficiências nutricionais em Brachiaria brizantha cv. Marandu. São Carlos, SP: Embrapa Pecuária Sudeste, 2007. 38 p. (Comunicado técnico, 76).

PINNOW, C. et al. Qualidade industrial do trigo em resposta à adubação verde e doses de nitrogênio. Bragantia, 72: 20-28, 2013.

PRADO, M. R.; CAMPOS, C. N. S. Nutrição e adubação de grandes culturas. Jaboticabal, SP: FCAV, 2018. 379 p.

RODRIGUES, F. et al. Aptidão de híbridos de milho para o consumo in natura. Revista de Ciências Agrárias. 41: 484-492, 2018.

SCHEIBLE, W. R.; GONZÁLES-FONTES, A.; LAUERER, M. Nitrateacts as a signaltointroduceorganicacidmetabolismandrepressst archmetabolism in tobacco. The PlantCell, 9: 783$798,1997$.

SILVA, F. A. S.; AZEVEDO, C. A. V. Principal Components Analysis in the Software AssistatStatistical Attendance. In: WORLD CONGRESS ON COMPUTERS IN AGRICULTURE, 7., 2009, Orlando. Proceedings... Reno. American Society of Agricultural and Biological Engineers, 2009.
SIQUEIRA NETO, M. et al. Mineralização e desnitrificação do nitrogênio no solo sob sistema plantio direto. Bragantia, 69: 923-936, 2010.

SORATTO, R. P.et al. Fontes alternativas e doses de nitrogênio no milho safrinha em sucessão a soja. Revista Ciência Agronômica, 41: 511-518, 2010.

SOUSA, D. M. G.; LOBATO, E. Cerrado: correção do solo e adubação. 2. ed. Brasilia, DF: Embrapa Informação Tecnológica, 2004. 416 p.

TAIZ, L.; ZEIGER, E. Fisiologia Vegetal. 5 ed. Porto Alegre, RS: Artmed, 2013, 918 p. 